\title{
THE Ag- AND Au-BEARING PHASES IN THE ESCONDIDA EPITHERMAL VEIN, CERRO MORO DEPOSIT, SANTA CRUZ, ARGENTINA
}

\author{
ANA C. MUGAS LOBOS ${ }^{\S}$ \\ CIGEOBIO, CONICET, Facultad de Ciencias Exactas, Físicas y Naturales, Universidad Nacional de San Juan, Av. Ignacio de \\ la Roza 590 (oeste), Rivadavia, J5402DCS, San Juan, Argentina \\ María Florencia MÁRQUEZ-ZAVALÍA
}

IANIGLA, CCT-Mendoza, CONICET, Av. Ruiz Leal s/n, Parque Gral. San Martín - C.C. 330 (5500) Mendoza, Argentina Mineralogía y Petrología, FAD, Universidad Nacional de Cuyo, Centro Universitario, (5502) Mendoza, Argentina

LAURA B. HERNÁNDEZ

Laboratorio de Microsonda Electrónica, Instituto GEA, Universidad de Concepción, Casilla 160C, Concepción, Chile

\begin{abstract}
The Cerro Moro deposit is located at $48^{\circ} 5^{\prime} 55^{\prime \prime} \mathrm{S}, 66^{\circ} 39^{\prime} 1.6^{\prime \prime} \mathrm{W}$ and 100 m.o.s.l. in Santa Cruz province, southern Argentina. It is a low sulfidation Au-Ag epithermal mineralization hosted by numerous NW-SE structurally controlled quartz veins developed in close spatial and temporal proximity to the products of Jurassic extension and magmatism. The Escondida vein is the most significant mineralized structure, as it hosts the base metal-rich and $\mathrm{Au}-\mathrm{Ag}$ high grade mineralization. In this vein and the Zoe ore-shoot, ore minerals are abundant (sphalerite, galena, chalcopyrite, acanthite, and less abundant pyrite and marcasite) and frequently related to dark grey, fine-grained quartz with massive, porous, crustiform, and banded textures; variable quantities of fine-grained flakes of muscovite are locally present. The Ag- and Au-bearing mineral association is represented by acanthite, argyrodite, polybasite, pearceite, stromeyerite, mckinstryite, and jalpaite. Abundant acanthite occurs commonly associated with gold and silver; copper enrichments were detected and interpreted as nanoinclusions of Cu-bearing minerals. The occurrence of Se- and Te-enriched minerals (acanthite, argyrodite, polybasite, pearceite, stromeyerite, and mckinstryite), rather than silver selenides and/or tellurides, indicates the presence of reduced mineralizing fluids and may be ascribed to partial substitution of S by Se or Te. Polybasite and pearceite were differentiated by their chemistry. Although the presence of argyrodite in epithermal deposits with silver sulfosalts is relatively common, this first mention in Cerro Moro is highly encouraging for exploration for germanium, a critical element, which is also considered strategic by countries such as the USA and China.
\end{abstract}

Keywords: precious metal minerals, epithermal deposit, Deseado Massif, Argentina.

\section{INTRODUCTION}

Cerro Moro $\left(48^{\circ} 5^{\prime} 55^{\prime \prime} \mathrm{S}, 66^{\circ} 39^{\prime} 1.6^{\prime \prime} \mathrm{W}\right)$ is a low sulfidation Au-Ag epithermal deposit located in Santa Cruz province, southern Argentina. It occurs in the Deseado Massif, a well-explored area where more than 20 epithermal Au-Ag mining projects have been discovered. On the basis of its gold content, the El Deseado Massif was classified as the El Deseado auriferous province by Zappettini (1999), and is characterized by vein-type low sulfidation epithermal mineralization, breccia deposits, disseminations, and placer and paleo-placer deposits, all developed in relation to rifting volcanism, where listric and transtensional faulting were dominant. In general, most of these mineralizations are of the vein-type, which is consistent with a strong structural control, i.e., the NNW-SSE and WNW-ESE principal orientation of

$\S$ Corresponding author e-mail address: amugas@unsj-cuim.edu.ar 
the extensional fault systems. Subparallel veining, stockwork mineralization, and disseminated mineralizations are less abundant (Schalamuk et al. 1999, Fernández et al. 2008, Andrada de Palomera et al. 2015).

Regarding their host rock, most of these deposits are spatially and temporally linked to the widespread Chon Aike rhyolitic province (Pankhurst et al. 1998), which is mainly composed of pyroclastic rocks dominated by rhyolitic ignimbrites with a consistent bimodality between rhyolite and andesite-basaltic andesite. This important Jurassic magmatism was emplaced over $\sim 30$ my (Early Jurassic-Late Jurassic), with three principal episodes representing the most intense phases of volcanic activity (Riley et al. 2001). Previous research (Pankhurst \& Rapela 1995, Pankhurst et al. 1998, 2000, Féraud et al. 1999, Riley et al. 2001, Panza \& Haller 2002, Echavarría et al. 2005, Giacosa et al. 2010, and references therein) proposed that the lithospheric extensions related to Gondwana break-up, the impact of a mantle plume, and/or the subduction along the paleo-Pacific margin may have been important in producing favorable tectonic conditions for the generation and emplacement of the silicic volcanic rocks. The metallogenetic importance of this Jurassic magmatism in Patagonia was first pointed out by Ramos (1983), who indicated that the occurrences of $\mathrm{Pb}, \mathrm{Zn}, \mathrm{Cu}, \mathrm{Ag}$, and $\mathrm{Au}$ mineralizations were coincident with episodes of stronger magmatic activity. Considering the age of the mineralizing and hydrothermal alteration processes in relation to their Jurassic host rock, a close relationship has been confirmed between them (e.g., Schalamuk et al. 1997, 1999, Echavarría et al. 2005, Fernández et al. 2008, Guido \& Campbell 2011, Jovic et al. 2011, Dietrich et al. 2012).

In this context, new mineralogical data from the Cerro Moro epithermal deposit are presented in this contribution. The characterization of the Ag- and Aubearing mineral association recognized in the Escondida vein structure and Zoe ore-shoot is provided here, together with electron probe microanalyses (EPMA) of the ore minerals identified in this contribution. Our study recognizes new minerals in the area as well as $\mathrm{Se}-$ and Te-enrichments in some mineral species.

\section{GEOLOGY}

\section{Regional geology}

The Cerro Moro deposit is located in the vicinity of Puerto Deseado city, in Santa Cruz province, Argentina. The regional geology includes fissural basalts and andesites from the Bajo Pobre formation (Panza 1982, 1984) which is of Middle Jurassic age. These are unconformably covered by the volcanic and volcano- sedimentary rock units of the Bahia Laura group (Lesta \& Ferello 1972) which contains the Chon Aike and the La Matilde formations (Ugarte 1966). These are vertically and laterally intercalated and are Middle Jurassic in age, based on the fossil content of the La Matilde formation (Stipanicic \& Reig 1955, 1956, Stipanicic \& Bonetti 1970). The Chon Aike formation is characterized by rhyolitic to rhyodacitic ignimbrites with volcanic agglomerates and breccias, subordinated quantities of tuff and rhyolitic domes, while the $\mathrm{La}$ Matilde formation is mainly composed of laminated tuffs and tuffaceous sediments interdigitated with thin ignimbrite layers (Panza et al. 1994, Pankhurst et al. 1998). The previous sequences are uncomformably covered by Upper Oligocene marine clastic rocks from the Monte León formation (Bertels 1970), including argillic tuffs, fine sandstones, and minor shales. The La Avenida formation (Marín 1982, Panza 1982), of Lower Pliocene age, overlies the previous rocks and features conglomerates intercalated with minor thin lenses of lithic sandstones. Finally, playa lake sediments with evaporitic crusts together with variable quantities of sand, mud, argillic sediments, and gravel, complete the modern sequence (Panza et al. 1994).

Two important tectonostratigraphic cycles were recognized and described by Cortiñas et al. (2005, as described in Giacosa et al. 2010): (1) a late Permian rifting expressed as $\mathrm{N}-\mathrm{S}$ trending fault systems, followed by continuous filling of the basin with sedimentary and volcanic rocks during TriassicLiassic thermal subsidence, and (2) a Jurassic extension in which a series of WNW-ESE grabens and half-grabens was filled with basic to felsic volcanic rocks.

The most relevant structural features in the Deseado Massif are the result of normal WNW-ESE and NNE to $\mathrm{N}-\mathrm{S}$ faulting associated with extension and rifting occurring throughout the Jurassic (Giacosa et al. 2010). These authors specified three main conclusions regarding the link between tectonics and epithermal mineralization: (1) the epithermal vein systems were controlled by distensive lineaments following the Jurassic extensional phase; (2) the SW-NE oriented extension controlled the opening of vein structures hosted within the Jurassic rhyolites and basalts, and in the prevolcanic strata, shear veins were emplaced into preexisting normal faults; and (3) the current crustal level to which the main mineralized system has been exhumed is the result of compressional deformation triggered by an inversion in the Cretaceous.

\section{Local geology}

The local geology (Fig. 1) is represented by felsic volcanic and volcano-sedimentary rocks with rhyolitic 


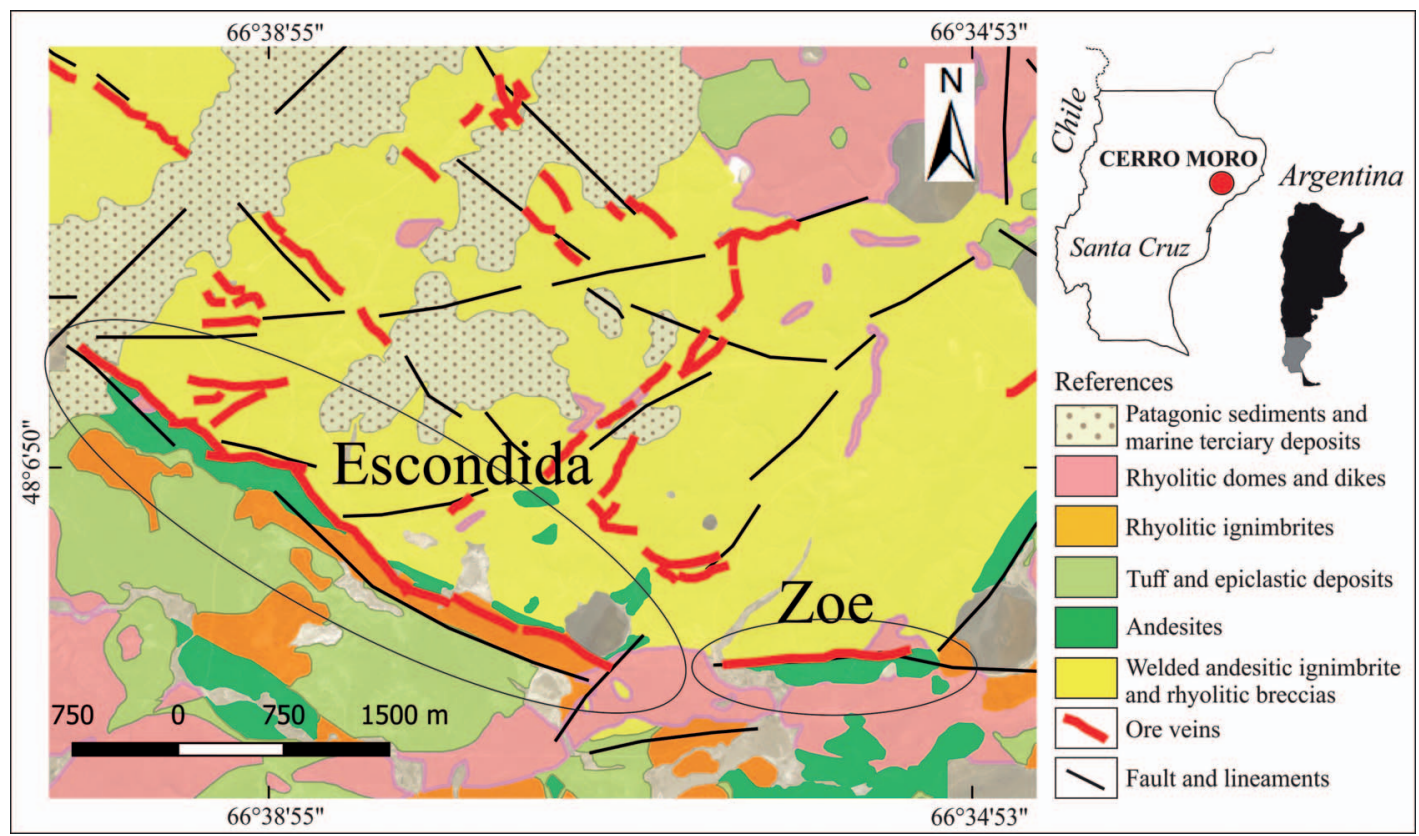

FIG. 1. Schematic geologic map of the Escondida vein structure and Zoe ore-shoot (modified from Guzman et al. 2012).

dome intrusions showing porphyritic, granular to porphyritic, and autobreccia textures, all belonging to the Jurassic Bahia Laura group (Ros et al. 2013); these volcanic sequences generally occur in layers with $\mathrm{W}-$ $\mathrm{SW}$ and E-SE direction and tilt $5^{\circ}$ to $20^{\circ}$ to the south.

The main fault system, predominantly developed on the southern part of the deposit, follows a NW-SE direction and controls the main mineralized structures. Other fault systems, strongly controlling the hydrothermal alteration and mineralization, occur in NE-SW, E$\mathrm{W}$, and N to NW-SE directions (Ros et al. 2013). Gallardo et al. (2015) pointed out that the volcanic sequences in the area were deposited in a NW-SE graben, mainly controlled by WNW normal faulting which resulted in horst and graben tectonics during the Jurassic extensional regime; this was followed in the Cretaceous by a more restricted compressional regime that triggered an inversion of the faults.

According to Sillitoe (2009), the NW-striking Escondida vein is a steeply south-dipping structure interpreted as a growth fault and bounding the southern side of a horst of Chon Aike rocks; during active faulting a sequence of predominantly andesitic epiclastic rocks accumulated along the hanging-wall side of the fault as the progressive infill to grabens or half-grabens. Corbett (2007) indicated that the structure is characterized by $\mathrm{N}-\mathrm{S}$ extension on NW and NE fractures, while small components of strike-slip movements - associated with this extension- resulted in dilatation on the $\mathrm{E}-\mathrm{W}$ vein portions of the NW fractures as settings for higher $\mathrm{Au}-\mathrm{Ag}$ grade polymetallic mineralization; this is the case for the Zoe ore-shoot. The width of the veins typically varies from 1 to $5 \mathrm{~m}$, but may locally attain up to $10 \mathrm{~m}$.

The Escondida vein is $8 \mathrm{~km}$ long and continues in deep $250 \mathrm{~m}$ below the present land surface (Guzman et al. 2012). This is the most significant structure in the Cerro Moro district, hosting the base metal-rich and high grade mineralization. Sillitoe (2009) indicated that the bonanza grade of the base metal-rich vein stage may be ascribed to intense boiling caused by sudden release of overpressured ascendant fluids, as suggested by the widely observed breccia and network vein textures typical of the occurrence of semi-massive sulfides.

On the basis of the hydrothermal alteration, the high $\mathrm{Au}$ and Ag-grades (<60 ppm Au and 10,000 ppm Ag) are closely related to the kaolinite subgroup and the mica-group minerals (Aliaga 2012). Corbett (2007) pointed out that these grades occur where fresh sulfides are in contact with halloysite (possibly halloysite- $7 \AA$ ); in this context this kaolinite-subgroup mineral is considered hypogenic. Corbett (2007) also suggested that mixing mineralizing fluids with acidic waters is the most efficient mechanism for the development of elevated Au grades in epithermal Au deposits such as Cerro Moro.

According to Yamana Gold Inc. (2017), the highgrade epithermal gold and silver deposits of Cerro 
Moro will be mined either through open pit or underground mining. During the second part of 2018, Cerro Moro reached commercial production and exceeded expectations with production of 92,793 ounces of gold and 4,119,085 ounces of silver (Yamana Gold Inc. 2018).

\section{Material AND Methods}

Thirty-five samples from the most mineralized sections of representative drill-holes were prepared as conventional polished thin sections and described in air and oil using polarizing reflected-light microscopes. Chemical analyses of acanthite, argyrodite, polybasite, and pearceite were obtained from the Laboratorio de Microsonda Electrónica, Instituto GEA, Universidad de Concepción (Chile), with a JEOL JXA 8600 Superprobe, using a beam diameter of $10 \mu \mathrm{m}$ and an acceleration potential of 20 and $25 \mathrm{kV}$. A sample current of $10 \mathrm{nA}$ was used, measured on a Faraday cup, and counting times of $30 \mathrm{~s}$ for $\mathrm{Au}, \mathrm{Ge}$, $\mathrm{Fe}, \mathrm{Se}, \mathrm{As}, \mathrm{Cu}, \mathrm{Sb}$, and $\mathrm{Te}$ and $20 \mathrm{~s}$ for $\mathrm{Ag}$ and $\mathrm{S}$. For the background, 15 and $10 \mathrm{~s}$ were used, respectively. The standards, analytical lines, and limits of detection (wt.\%) were as follows: $\mathrm{Ag}$ (silver, $L \alpha, 0.12$ ), Se (CdSe, $K \alpha, 0.16$ ), As (InAs, $K \alpha, 0.12$ ), S (stibnite, $K \alpha$, 0.03 ), Fe (chalcopyrite, $K \alpha, 0.03$ ), Te (SbTe, $L \alpha, 0.07$ ), $\mathrm{Au}$ (gold, $M \alpha, 0.14$ ), $\mathrm{Sb}$ (stibnite, $L \alpha, 0.05$ ), $\mathrm{Cu}$ (chalcopyrite, $K \alpha, 0.04$ ), Ge (germanium, $K \alpha, 0.11$ ). A ZAF correction routine was used. Additional data for gold, silver, acanthite, argyrodite, stromeyerite, mckinstryite, and jalpaite were obtained from the Laboratorio de Microscopía Electrónica y Análisis por Rayos X (LAMARX), Universidad Nacional de Córdoba (Argentina), with a JEOL JXA 8230 Superprobe, using a beam diameter of $2 \mu \mathrm{m}$ and an acceleration potential of $15 \mathrm{kV}$. A sample current of 10 and $20 \mathrm{nA}$ was used, measured from a Faraday cup, and a counting time of $10 \mathrm{~s}$ and $5 \mathrm{~s}$ for the background for all elements but $\mathrm{Ge}$ and $\mathrm{Ag}(5 \mathrm{~s}$ for the element and $2.5 \mathrm{~s}$ for the background) and $\mathrm{S}$ (6 $\mathrm{s}$ for element and $3 \mathrm{~s}$ for the background). The standards, analytical lines, and limits of detection (wt.\%) were as follows: Ag (silver, $L \alpha, 0.04$ ), Se (NiSe, $L \alpha, 0.02$ ), Sn (tin, $L \alpha$, 0.02), As (nickeline, $L \beta, 0.04), \mathrm{Pb}$ (lead/galena, $M \beta$, 0.09 ), $\mathrm{S}$ (pyrite/galena, $K \alpha, 0.01$ ), Fe (hematite, $K \alpha$, 0.03 ), Te (coloradoite, $L \alpha, 0.03$ ), $\mathrm{Zn}$ (sphalerite, $K \alpha$, 0.04), $\mathrm{Au}$ (gold, $M \alpha, 0.02$ ), $\mathrm{Sb}$ (stibnite, $L \alpha, 0.02$ ), $\mathrm{Cu}$ (chalcopyrite, $K \alpha, 0.04)$, $\mathrm{Ge}\left(\mathrm{Bi}_{12} \mathrm{GeO}_{20}, L \alpha, 0.04\right)$. A CIT-ZAF correction routine was used.

\section{The Silver- and Gold-Bearing Mineral Association}

Based on the vein mineralogy, textures, and cross cutting relationships, four mineralizing stages were identified at Cerro Moro. The first stage is characterized by whitish grey and locally violet-colored quartz \pm adularia veins $(<20 \mathrm{~cm}$ thick $)$, with scarce quantities of pyrite and galena. The most common textures are replacement lattice and parallel bladed quartz; comb and massive textures are poorly represented. The second stage is characterized by quartzadularia ( \pm fluorite) veins ( $\sim 5 \mathrm{~cm}$ thick) with variable quantities of pyrite, sphalerite, chalcopyrite, galena, acanthite, and gold, locally attaining $20 \%$ in volume. The main primary textures in the veins are comb, crustiform, and botroidal. The third stage of mineralization occurs as veins ( $<35 \mathrm{~cm}$ thick) and cementing fragments of previous brecciated veins. This mineralizing stage is known as "Black Silica", being dark grey in color and mainly composed of fine-grained to variable sized subhedral quartz grains (up to $2 \mathrm{~mm}$ ) associated with variable quantities of fine-grained flakes and patches of muscovite; the most abundant ore minerals are $\mathrm{Fe}$-poor sphalerite, chalcopyrite, galena, and acanthite, with lesser pyrite and marcasite. Gold of varying fineness and silver may locally reach high grades, such as $536 \mathrm{~g} / \mathrm{t} \mathrm{Au}$ and $11300 \mathrm{~g} / \mathrm{t} \mathrm{Ag}$. Representative textures are massive, crustiform, and banded. The last stage of mineralization is represented by light grey whitish and lesser light violet quartz adularia \pm chalcedony \pm calcite veins $(<15 \mathrm{~cm}$ thick $)$ with variable quantities of sphalerite, chalcopyrite, and less abundant pyrite, acanthite, and gold. Comb and infilling textures are common.

According to Guzman et al. (2012), up to $42.8 \%$ and $19.8 \%$ of the total mineralization in Cerro Moro is contained in the Escondida vein and Zoe ore-shoot, respectively. In these mineralized structures ore minerals are mainly related to the third stage of mineralization. A detailed study of polished thin sections led to the identification of precious-metal bearing minerals hosted in the quartz veins and the hydrothermal breccias of the third stage of mineralization. In addition to gold, silver, and acanthite, the presence of polybasite, pearceite, stromeyerite, mckinstryite, argyrodite, and jalpaite is reported for the first time in Cerro Moro.

Gold grains are common. They occur in quartz as irregular isolated grains from 10 to $60 \mu \mathrm{m}$ in size, occasionally up to $750 \mu \mathrm{m}$. Gold is also related to acanthite, developing irregular inclusions and as exsolved grains and blebs (10 to $230 \mu \mathrm{m})$. Occasionally it may be found as inclusions $(\sim 15 \mu \mathrm{m})$ in pyrite and/or chalcopyrite (Fig. 2a, b); locally, vermicular grains of gold may infill fractures in pyrite grains. The gold fineness ranges from 315 to 762 , therefore from Au-rich silver to Ag-rich gold. The compositions of representative gold grains indicate that, besides $\mathrm{Ag}$, Te 

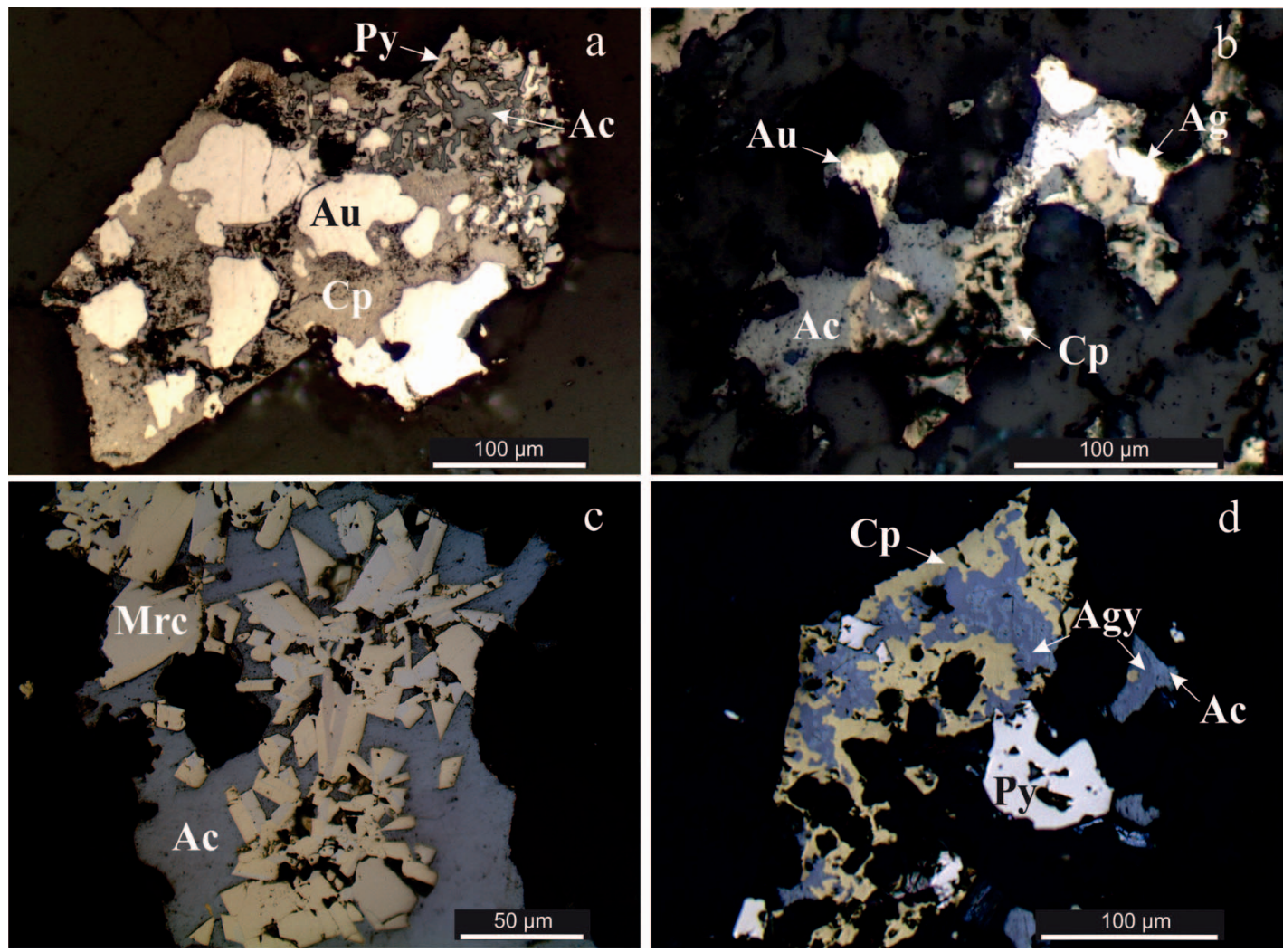

FIG. 2. Photomicrography mosaic showing: (a) Chalcopyrite (Cp)-gold (Au) intergrowth; pyrite (Py) and acanthite (Ac) developing a worm-like texture. (b) Acanthite associated with chalcopyrite, gold (Au), and silver (Ag). (c) Acanthite and marcasite (Mrc) aggregate. (d) Argyrodite (Agy) partially replacing acanthite on grain boundaries; chalcopyrite and lesser pyrite are also present.

and $\mathrm{S}$ may be present (up to 0.27 and 0.23 wt.\%, respectively).

Silver grains ( $\sim 50$ to $200 \mu \mathrm{m})$ are less abundant than Au-rich silver or Ag-rich gold grains. They were observed spatially related to acanthite, chalcopyrite (Fig. 2b), and, to a lesser extent, sphalerite and pyrite. In general, $\mathrm{S}, \mathrm{Cu}$, and Te contents measured by EPMA were 0.05 to 1.66 wt. $\%, 0.08$ to 0.22 wt. $\%$, and 0.30 to 0.45 wt. $\%$, respectively.

Acanthite is abundant and widespread (Figs. 2 and $3)$. It occurs as olive-grey colored irregular grains ( $\sim 200-600 \mu \mathrm{m})$, usually found included in quartz and/ or as thin veinlets associated with chalcopyrite and galena. Acanthite is usually found with irregular gold inclusions $(\sim 10 \mu \mathrm{m})$ or spatially associated with silver grains and gold grains $(\sim 30 \mu \mathrm{m}$ to $<230 \mu \mathrm{m})$ of varying fineness. It commonly occurs replacing galena on its margins and, to a lesser extent, chalcopyrite. Electron probe microanalysis results show some variations in acanthite chemistry where variable concentrations of $\mathrm{Te}, \mathrm{Cu}$, and $\mathrm{Se}$ were detected in different samples (Table 1).

Polybasite occurs as irregular grains in the range 10 to $80 \mu \mathrm{m}$ and occasionally up to $3 \mathrm{~mm}$. Polybasite grains are not very abundant; they partially replace pearceite (Fig. 3a, b) and are in close association with galena, acanthite, and chalcopyrite. Polybasite may be locally replaced by acanthite along grain boundaries (Fig. 3d) and fractures; locally, thin margins of chalcopyrite may develop in the contact between these minerals.

Pearceite grains $(<80 \mu \mathrm{m})$ are less abundant compared to polybasite. Clear differentiation of these two minerals by optical microscopy was impossible, mainly due to their similar optical properties; EPMA was used to distinguish them. Representative chemical analyses of both are presented in Table 1 .

Stromeyerite and mckinstryite generally occur in close proximity, as irregular aggregates ( $\sim 20$ to 120 $\mu \mathrm{m})$. Mckinstryite is commonly found replacing 

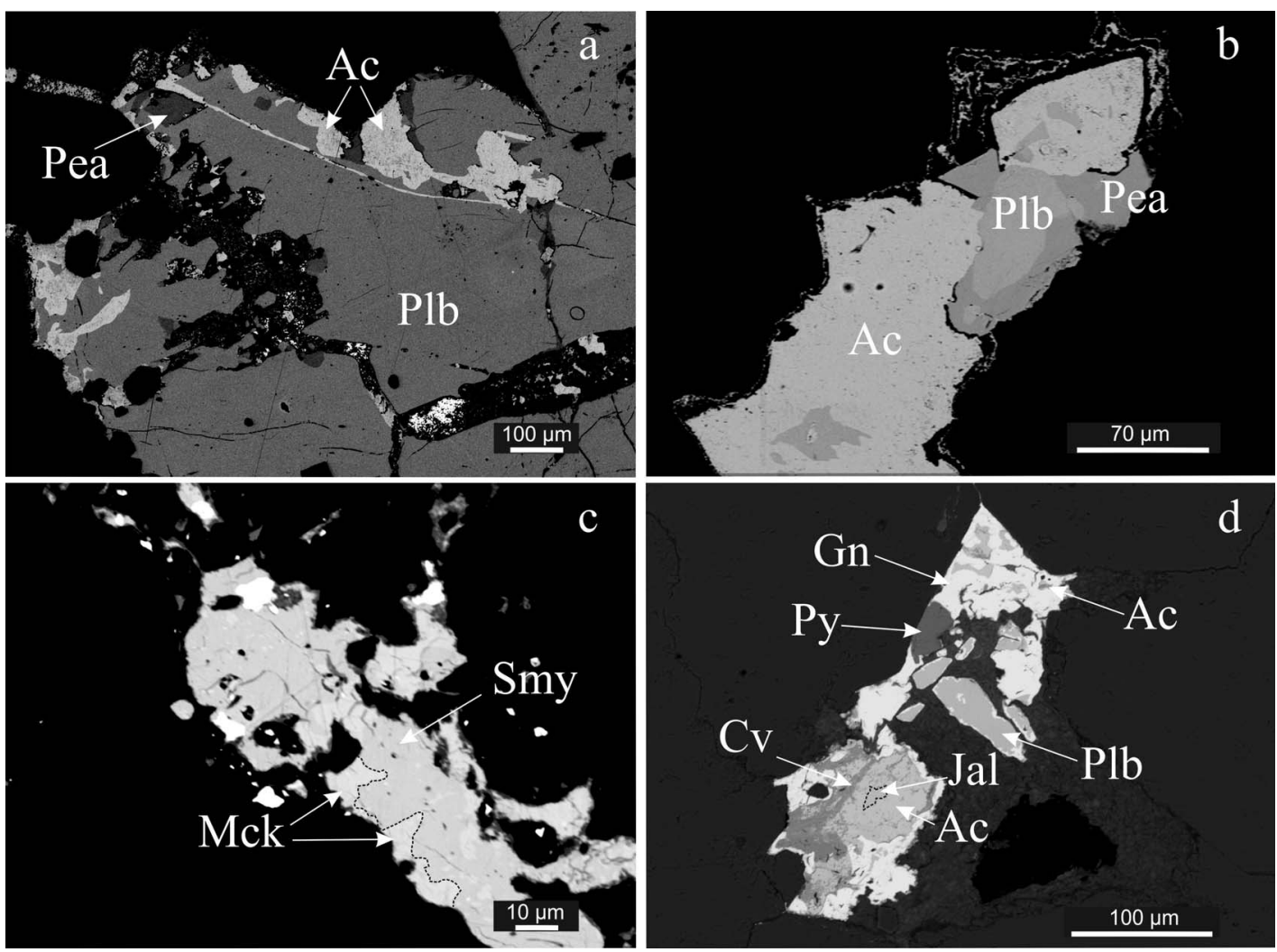

FIG. 3. BSE image mosaic. (a) Polybasite (Plb) grains partially replaced by pearceite (Pea); both replaced by acanthite. (b) Acanthite partially replacing polybasite and pearceite. (c) Stromeyerite (Smy) partially replaced by mckinstryite (Mck) on grain boundaries. (d) A small jalpaite (Jal) grain closely related to acanthite.

stromeyerite on grain boundaries and fracture lines (Fig. 3c); stromeyerite may partially replace chalcopyrite. Small grains of covellite partially replace stromeyerite along cleavage planes. Electron probe microanalysis of stromeyerite shows slight enrichment in $\mathrm{S}$ and depletion in $\mathrm{Ag}$ (Table 1). The calculated mineral formula is $\left(\mathrm{Cu}_{0.99} \mathrm{Ag}_{0.83} \mathrm{Fe}_{0.11}\right)_{\Sigma 1.93} \mathrm{~S}_{1.06}$. The chemical composition of mckinstryite is in good agreement with published values for this mineral; the calculated empirical formula is $\left(\mathrm{Ag}_{1.16} \mathrm{Cu}_{0.81}\right.$ $\left.\mathrm{Fe}_{0.01}\right)_{\Sigma 1.98} \mathrm{~S}_{1.01}$.

Argyrodite was locally identified; it is very scarce and occurs as small grains $(<20 \mu \mathrm{m}$, Fig. $2 \mathrm{~d})$ forming aggregates with acanthite. Two representative chemical analyses of this mineral are presented in Table 1, where only minor amounts of $\mathrm{Fe}$ (up to $0.95 \mathrm{wt} . \%$ ), $\mathrm{Cu}$ (up to 0.89 wt. $\%$ ), and Te (up to 0.46 wt.\%) were detected; small quantities of Se were locally present. The average mineral formula is $(n=5)\left(\mathrm{Ag}_{8.02}, \mathrm{Cu}_{0.11}\right)_{\Sigma 8.13}$ $\left(\mathrm{Ge}_{0.84} \mathrm{Fe}_{0.13}\right)_{\Sigma 0.97}\left(\mathrm{~S}_{5.85}, \mathrm{Te}_{0.03} \mathrm{Se}_{0.02}\right)_{\Sigma 5.90}$.
Small grains of jalpaite (up to $6 \mu \mathrm{m}$ in size) are very scarce and were found spatially related to acanthite and, to a lesser extent, pyrite, chalcopyrite, galena, polybasite, and covellite (Fig. 3d). Due to its small size, the identification of this mineral was done on the basis of its chemical composition by EMPA (Table 1). The calculated empirical formula is $\mathrm{Ag}_{2.97} \mathrm{Cu}_{1.01} \mathrm{~S}_{2.02}$

\section{DiscusSION}

The mineralization in Cerro Moro, and especially in the Escondida vein and Zoe ore-shoot area, was strongly controlled by the Jurassic extensional regime. As previously noted by Corbett (2007), the extension of NW-SE fractures and associated dilatation on E-W vein portions of NW fractures were important features as settings for higher $\mathrm{Au}-\mathrm{Ag}$ grade polymetallic mineralization, which is the case for Escondida and Zoe. 
TABLE 1. REPRESENTATIVE CHEMICAL COMPOSITIONS OF THE Ag-BEARING MINERAL ASSOCIATION

\begin{tabular}{|c|c|c|c|c|c|c|c|c|c|c|c|}
\hline & \multicolumn{2}{|c|}{ Acanthite } & \multicolumn{2}{|c|}{ Argyrodite } & \multicolumn{2}{|c|}{ Polybasite } & \multicolumn{2}{|c|}{ Pearceite } & \multirow{2}{*}{$\frac{\text { Stromeyerite }}{1}$} & \multirow{2}{*}{$\frac{\text { Mckinstryite }}{1}$} & \multirow{2}{*}{$\frac{\text { Jalpaite }}{1}$} \\
\hline & 1 & 2 & 1 & 2 & 1 & 2 & 1 & 2 & & & \\
\hline S (wt.\%) & 13.24 & 15.13 & 17.41 & 17.06 & 15.36 & 15.23 & 16.22 & 14.88 & 17.42 & 15.40 & 14.55 \\
\hline $\mathrm{Fe}$ & b.d.I. & b.d.I & 0.95 & 0.37 & b.d.I & b.d.I. & 0.04 & 0.15 & 3.29 & 0.33 & b.d.l. \\
\hline $\mathrm{Cu}$ & 0.04 & 0.67 & 0.54 & 0.14 & 7.37 & 8.67 & 8.95 & 6.08 & 32.50 & 24.39 & 14.33 \\
\hline $\mathrm{Zn}$ & 0.17 & n.a. & n.a. & 0.09 & n.a. & n.a. & n.a. & n.a. & b.d.l. & b.d.I. & 0.22 \\
\hline $\mathrm{Ge}$ & n.a. & n.a. & 5.20 & 5.93 & n.a. & n.a. & n.a. & n.a. & n.a. & n.a. & n.a. \\
\hline As & n.a. & n.a. & b.d.l. & n.a. & 0.79 & 2.13 & 6.89 & 5.85 & n.a. & n.a. & b.d.I. \\
\hline $\mathrm{Se}$ & b.d.l. & b.d.l. & b.d.I. & 0.17 & 0.23 & b.d.l. & b.d.I. & 0.20 & 0.07 & b.d.l. & b.d.l. \\
\hline $\mathrm{Ag}$ & 87.01 & 84.18 & 75.47 & 76.44 & 66.15 & 66.64 & 67.06 & 71.83 & 46.07 & 59.35 & 71.78 \\
\hline $\mathrm{Sb}$ & b.d.l. & n.a. & b.d.I. & b.d.l. & 10.22 & 7.35 & 0.54 & 0.46 & b.d.l. & b.d.l. & b.d.l. \\
\hline $\mathrm{Te}$ & 0.30 & n.a. & 0.25 & 0.37 & n.a. & n.a. & n.a. & n.a. & 0.16 & 0.19 & b.d.I. \\
\hline $\mathrm{Au}$ & b.d.l. & b.d.l. & b.d.I. & b.d.l. & b.d.I. & b.d.I. & b.d.I. & b.d.I. & 0.17 & 0.22 & b.d.I. \\
\hline $\mathrm{Pb}$ & 0.15 & n.a. & n.a. & b.d.I. & n.a. & n.a. & n.a. & n.a. & 0.43 & b.d.I. & b.d.l. \\
\hline Total & 100.91 & 99.98 & 99.82 & 100.49 & 100.11 & 100.02 & 99.70 & 99.46 & 100.11 & 99.88 & 100.66 \\
\hline S (apfu) & 1.01 & 1.12 & 6.07 & 5.97 & 10.64 & 10.45 & 10.74 & 10.25 & 1.06 & 1.01 & 2.02 \\
\hline $\mathrm{Fe}$ & - & - & 0.19 & 0.07 & - & - & 0.02 & 0.06 & 0.11 & 0.01 & - \\
\hline $\mathrm{Cu}$ & 0.00 & 0.03 & 0.10 & 0.02 & 2.58 & 3.00 & 2.99 & 2.11 & 0.99 & 0.81 & 1.01 \\
\hline $\mathrm{Zn}$ & 0.01 & - & - & 0.02 & - & - & - & - & - & - & - \\
\hline $\mathrm{Ge}$ & - & - & 0.80 & 0.92 & - & - & - & - & - & - & - \\
\hline As & - & - & - & - & 0.23 & 0.63 & 1.95 & 1.72 & - & - & - \\
\hline $\mathrm{Se}$ & - & - & - & 0.02 & 0.06 & - & - & 0.06 & 0.00 & - & - \\
\hline $\mathrm{Ag}$ & 1.97 & 1.85 & 7.82 & 7.95 & 13.62 & 13.59 & 13.20 & 14.71 & 0.83 & 1.16 & 2.97 \\
\hline $\mathrm{Sb}$ & - & - & - & - & 1.86 & 1.33 & 0.09 & 0.08 & - & - & - \\
\hline $\mathrm{Te}$ & 0.01 & - & 0.02 & 0.03 & - & - & - & - & 0.00 & 0.00 & - \\
\hline $\mathrm{Au}$ & - & - & - & - & - & - & - & - & 0.00 & 0.00 & - \\
\hline $\mathrm{Pb}$ & - & - & - & - & - & - & - & - & 0.01 & - & - \\
\hline Total & 3.00 & 3.00 & 15.00 & 15.00 & 29.00 & 29.00 & 29.00 & 29.00 & 3.00 & 3.00 & 6.00 \\
\hline
\end{tabular}

b.d.I. = bellow detection limit. n.a. = not analyzed. Bismuth and Sn were always under the limits of detection.

The ore minerals described in this contribution, including gold, silver, acanthite, polybasite, pearceite, stromeyerite, mckinstryite, argyrodite, and jalpaite, are characteristic of epithermal type deposits; most of them, except gold, silver, and acanthite, are reported for the first time in the Cerro Moro area.

Gold and pure silver grains are commonly found in vein samples from most mineralizing stages. The former is absent in the second stage, while $\mathrm{Ag}$ was only identified in the third stage of mineralization. Both minerals are usually related to acanthite and, to a minor extent, pyrite and chalcopyrite. Gold is very common and widely distributed mainly as an alloy; no further controls on the spatial distribution of these minerals were identified.

Besides gold and silver, the most abundant and widespread precious metal mineral in the Escondida vein is acanthite. It is found in most samples and is usually related to galena and, to a lesser extent, chalcopyrite and sphalerite, being younger than the base metal minerals. Though $\mathrm{Cu}$-enrichment was detected in many grains of acanthite $(0.17$ to 2.47 wt.\%), previous observations from Ramdohr (1980) and others indicate that no extensive $\mathrm{Cu}$ content can be held by the acanthite structure. On the basis of this information and the close association of this mineral with jalpaite, chalcopyrite, and covellite, it might be possible that the $\mathrm{Cu}$ content in acanthite is due to nanoinclusions of these $\mathrm{Cu}$-bearing minerals. Moreover, Shikazono (1978) indicates that this apparent $\mathrm{Cu}$ content in acanthite may be attributed to EMPA analyses that incorporate $\mathrm{Cu} \mathrm{X}$-rays from chalcopyrite which encloses the acanthite, which may locally explain some of the acanthite $\mathrm{Cu}$ enrichment.

Based on previous research (e.g., Petruk \& Owens 1974, Petruk et al. 1974, Shikazono 1978, Simon et al. 1997, Cocker et al. 2012), the presence of Se and Te in acanthite is not uncommon in epithermal deposits. In Cerro Moro, only isolated contents of Se were detected in acanthite (up to $3.45 \mathrm{wt} . \%$ ) and, to a lesser extent, in argyrodite, polybasite, pearceite, and stromeyerite (Table 1). The occurrence of Se-enriched minerals rather than silver selenides may indicate a low $\mathrm{Se} / \mathrm{S}$ ratio in the ore fluids and also that the oxidizing state 


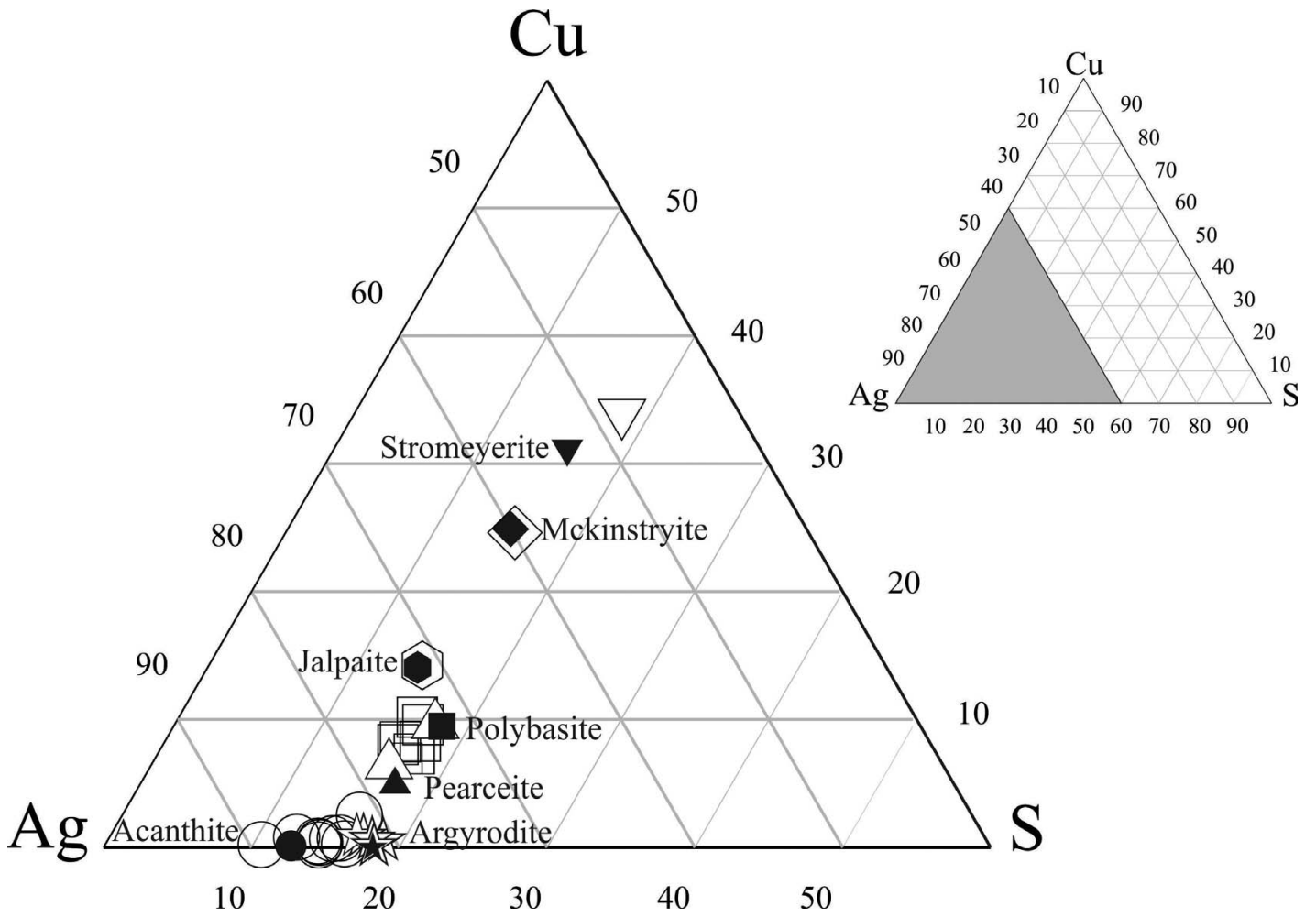

FIG. 4. S-Cu-Ag triangular plot of the Au- and Ag-bearing mineral association from the Escondida vein and Zoe ore-shoot. Analyses provided in this contribution are plotted as open white symbols; the ideal composition of mineral species are indicated for reference and plotted as solid black symbols.

in the mineralizing fluid was below or very close to the hematite-magnetite buffer, leading to reduced fluids (Simon et al. 1997). The latter is confirmed by the absence of hypogene hematite in the mineral association. As it is frequent in Toyoha $(\mathrm{Pb}-\mathrm{Zn})$ and Ikuno (polymetallic) vein-type deposits (Shikazono 1978), and $\mathrm{Au}-\mathrm{Ag}$ epithermal deposits, where selenium cannot be separated effectively from sulfur during mineral deposition (Simon et al. 1997). In most contemporary interpretations, Te and Se are considered to be transported as aqueous species and vapor in epithermal fluids (Ciobanu et al. 2006, Saunders \& Brueseke 2012). On the basis of these observations we consider that both $\mathrm{Se}-$ and Te-enrichments in the Agbearing sulfides from Cerro Moro are possibly due to their scarcity in the fluids, allowing only a partial substitution of $\mathrm{S}$ by those elements.

In this article, argyrodite grains are reported from the Cerro Moro deposit for the first time. Scarce grains of this mineral occur in isolation or related to acanthite and chalcopyrite. Based on the composition of the argyrodite, a slight enrichment in $\mathrm{Cu}, \mathrm{Te}$, and Se was detected. Tin was analyzed but not detected. The presence of argyrodite, even if scarce, may be an indication of the high sulfur activity of the mineralizing fluids, because when the sulfur activity is low to moderate, germanium concentrates in sphalerite and does not form its own sulfides. Therefore, the presence of Fe-poor sphalerite grains $(<1.88$ wt.\% Fe) in the third stage of the mineralization may be indicative of a high sulfur pressure in the fluid from which deposition took place (Ramdohr 1980). Thought not abundant, the presence of argyrodite indicates the potentiality to find more critical element-bearing minerals in the area.

$\mathrm{The} \mathrm{Cu}-\mathrm{Ag}-\mathrm{S}$ ternary system represented in Figure 4 summarizes most of the minerals described in this contribution, where ideal compositions were also plotted for comparison. According to Skinner (1966), the exceedingly fast reaction rates encountered throughout this particular system demonstrate that very few of the observed assemblages are likely to preserve an unaltered record of the specific conditions of ore formation, even of supergene processes. An example of the later is the intimate association of acanthite and jalpaite (Fig. 3d), which may be interpreted as the breakdown product of a pre-existing 

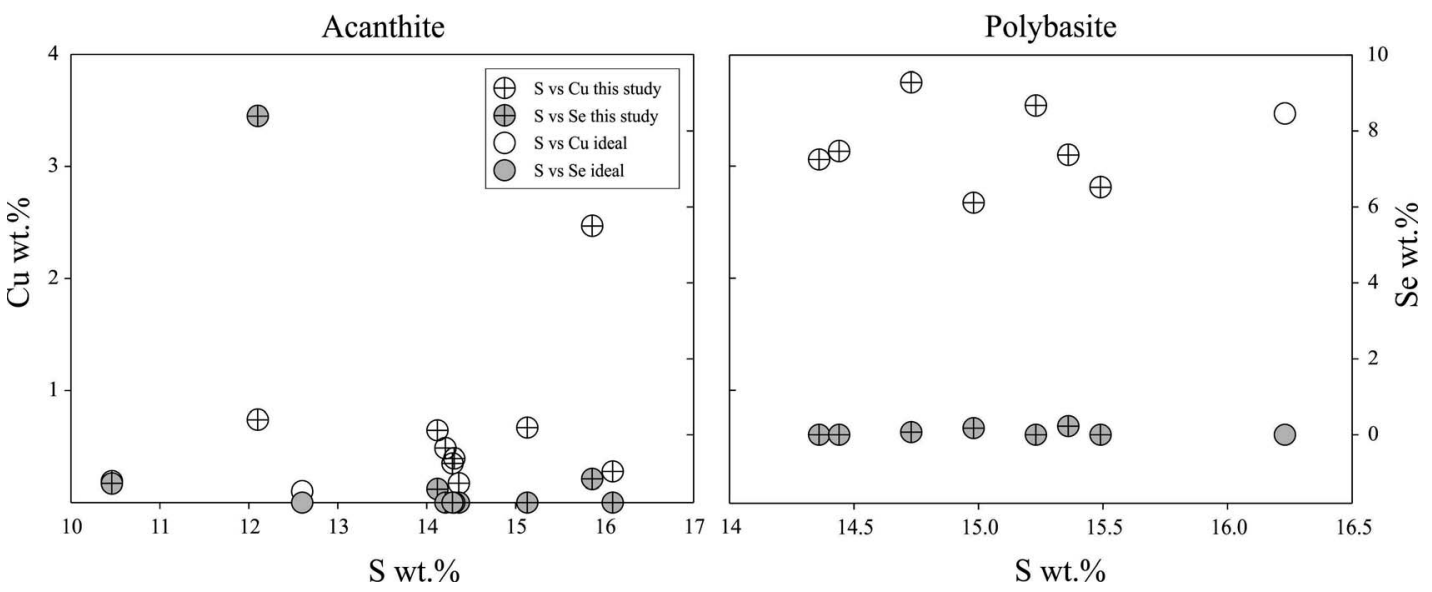

Fig. 5. S versus $\mathrm{Cu}$ and $\mathrm{Se}$ combined diagrams for acanthite (left side) and polybasite (right side). White crossed-circle symbols indicate $\mathrm{Cu}$ contents in relation to $\mathrm{S}$; grey crossed-circle symbols indicate Se contents in relation to $\mathrm{S}$; clear white and grey circular symbols indicate ideal $\mathrm{Cu}$ and $\mathrm{Se}$ contents for each mineral.

$\mathrm{Cu}$-rich acanthite grain, indicating a deposition temperature higher than $176.7^{\circ} \mathrm{C}$. This interpretation may locally explain the $\mathrm{Cu}$ contents in acanthite. Shikazono (1978) indicated that although the area of analysis would now be composed of a mixture of two phases, such as acanthite and jalpaite, it is certain that one homogeneous phase containing considerable amounts of $\mathrm{Cu}$, and $\mathrm{Se}$ when Se-enrichment is present, was originally precipitated at the time of the ore deposition.

The $\mathrm{S}$ versus $\mathrm{Cu}$ and Se diagram for acanthite (Fig. 5a) confirms previous observations regarding $\mathrm{Cu}$ and Se contents in the acanthite from the study area, with a wide range of variability in their quantities. Selenium and $\mathrm{Cu}$ contents in polybasite (Fig, 5b) match well its ideal composition (Bindi et al. 2007).

\section{Conclusions}

A distinct Ag- and Au-bearing mineral association related to the Jurassic magmatism and metallogenesis at the Cerro Moro deposit has been described in this contribution. Based mainly on the mineral occurrence, associations, and chemistry, the main conclusions are:

1) Gold and silver are common and widespread in the area; gold is frequently found as an alloy, with $\mathrm{Au}$ contents reaching up to 76 wt.\%; high-fineness silver is less abundant than Au-rich silver and Agrich gold.

2) Acanthite is very common and abundant, generally replacing galena and polybasite. A fine mixture of jalpaite and acanthite was observed and may be interpreted as the breakdown product of a preexisting $\mathrm{Cu}$-rich acanthite grain; this observation may partially explain the $\mathrm{Cu}$-enrichment in some acanthite grains.

3) The occurrence of Se-enriched minerals rather than silver selenides likely indicates a low $\mathrm{Se} / \mathrm{S}$ ratio in the ore fluids and also a reduced state. The presence of scarce tellurium in the sulfides from the study area is probably related to a low Te content in the mineralizing fluid, considering that this element is highly incompatible. Though the presence of argyrodite is relatively common in several epithermal deposits from Bolivia and Argentina, this first mention in Cerro Moro may indicate that other Gebearing mineral species may be present as well, improving the economic potential of this deposit in relation to this critical or strategic element. More complete mineralogical investigation of the Cerro Moro vein system is required to evaluate this potential.

\section{ACKNOWLEDGMENTS}

The authors are grateful to the Consejo Nacional de Investigaciones Científicas y Técnicas (CONICET), Argentina, for financial support through a postdoctoral fellowship and the RD1163 ( $\left.{ }^{\circ} 52531\right)$ funding given to ACMG and to the Agencia Nacional de Promoción Científica y Tecnológica y Fondo para la Investigación Científica y Tecnológica (AGENCIA-FONCyT) through the PICT 2015-0224. Special thanks are extended to Extorre Gold Mines Limited and Yamana Gold Inc. for granting the authors (ACML and MFMZ) access to the deposit and for contributing information, samples, and financial support. The authors are also very grateful for the constructive reviews of $\mathrm{D}$. 
McLeish and B. Rottier. The editorial handling and comments of Associate Editor M. Steele-MacInnis are much appreciated.

\section{REFERENCES}

Aliaga, G. (2012) Alteración Hidrotermal de la veta Escondida y Zoe. Proyecto C $C^{\circ}$ Moro-Puerto DeseadoSta. Cruz-Argentina. Trabajo final de Licenciatura (inédito), Facultad de Tecnología y Ciencias Aplicadas, Departamento de Geología, Universidad Nacional de Catamarca, San Fernando del Valle de Catamarca, Argentina, $124 \mathrm{pp}$.

Andrada de Palomera, P., van Ruitenbeek, F.J.A., \& Carranza, E.J.M. (2015) Prospectivity for epithermal gold-silver deposits in the Deseado Massif, Argentina. Ore Geology Reviews 71, 484-501.

Bertels, A. (1970) Sobre el "Piso Patagonian" y la representación de la época del Oligoceno en Patagonia austral, República Argentina. Revista de la Asociación Geológica Argentina 25(4), 495-501.

Bindi, L., Evain, M., Spry, P.G., \& Menchetti, S. (2007) The pearceite-polybasite group of minerals: Crystal chemistry and new nomenclature rules. American Mineralogist 92, 918-925.

Ciobanu, C.L., Cook, N.J., \& Spry, P.G. (2006) Prefacespecial issue: Telluride and selenide minerals in gold deposits-how and why? Mineralogy and Petrology 87, 163-169.

Cocker, H.A., Mauk, J.L., \& Rabone, S.D.C. (2012) The origin of $\mathrm{Ag}-\mathrm{Au}-\mathrm{S}-\mathrm{Se}$ minerals in adularia-sericite epithermal deposits: Constraints from the Broken Hills deposit, Hauraki Goldfield, New Zealand. Mineralium Deposita 48, 249-266.

Corbett, G. (2007) Comments on the Cerro Moro and La Calandria projects, Argentine Patagonia. Internal report prepared by Corbett Geological Services Pty. Ltd., Draft as of March $5^{\text {th }}, 2007,27 \mathrm{pp}$.

Dietrich, A., Gutierrez, R., Nelson, E.P., \& Layer, P.W. (2012) Geology of the epithermal Ag-Au Huevos Verdes vein system and San José district, Deseado massif, Patagonia, Argentina. Mineralium Deposita 47, 233-249.

Echavarkía, L.E., Schalamuk, I.B., \& Etcheverry, R.O. (2005) Geologic and tectonic setting of Deseado Massif epithermal deposits, Argentina, based on El DoradoMonserrat. Journal of South American Earth and Sciences 19, 415-432.

Féraud, G., Alric, V., Fornari, M., Bertrand, H., \& Haller, M. (1999) ${ }^{40} \mathrm{Ar} /{ }^{39} \mathrm{Ar}$ dating of the Jurassic volcanic province of Patagonia: Migrating magmatism related to Gondwana break-up and subduction. Earth and Planetary Science Letters 172, 83-96.

Fernández, R.R., Blesa, A., Moreira, P., Echeveste, H., Mykietiuk, K., Andrada de Palomera, P., \& Tessone, M.
(2008) Los Depósitos de oro y plata vinculados al Magmatismo Jurásico de la Patagonia: Revisión y perspectivas para la exploración. Revista de la Asociación Geológica Argentina 63(4), 665-681.

Gallardo, J., Di Caro, J., Munizaga, W., \& Vera, D. (2015) Geology and Genesis of multistage of epithermal Au-Ag Cerro Moro Deposits. Congreso Geológico Chileno, La Serena, Chile.

Giacosa, R., Zubia, M., Sánchez, M., \& Allard, J. (2010) Meso-Cenozoic tectonics of the southern patagonian foreland: Structural evolution and implications for $\mathrm{Au}-$ $\mathrm{Ag}$ veins in the Eastern Deseado región (Santa Cruz, Argentina). Journal of South American Earth Sciences 30, $134-150$.

Guido, D.M. \& CAmpbell, K.A. (2011) Jurassic hot springs deposits of the Deseado Massif (Patagonia, Argentina): Characteristics and controls on regional distribution. Journal of Volcanology and Geothermal Research 203, 35-47.

Guzman, C., Gosling, B., Coupland, D., Sanford, A., Sinha, K., \& Gabora, M. (2012) Preliminary economic assessment for the Cerro Moro gold-silver project, Santa Cruz province, Argentina. Technical Report NI 43-101, 338 pp.

Jovic, S.M., Guido, D.M., Schalamuk, I.B., Ríos, F.J., Tassinari, C.C.G., \& Recio, C. (2011) Pingüino Inbearing polymetallic vein deposit, Deseado Massif, Patagonia, Argentina: Characteristics of mineralization and ore-forming fluids. Mineralium Deposita 46, $257-$ 271.

Lesta, P. \& Ferello, R. (1972) Región Extraandina de Chubut y Norte de Santa Cruz. In Geología Regional Argentina (A. Leanza, ed.). Academia Nacional de Ciencias, Córdoba, Spain (602-687).

Marín, G. (1982) Descripción geológica de la Hoja 55c "Gobernador Gregores" provincia de Santa Cruz. Informe preliminar, Servicio Geológico Nacional (inédito), 17 pp. (in Spanish).

Pankhurst, R.J. \& Rapela, C.W. (1995) Production of Jurassic rhyolite by anatexis of the lower crust of Patagonia. Earth and Planetary Science Letters 134(12), 23-36.

Pankhurst, R.J., Leat, P.T., Sruoga, P., Rapela, C.W., Márquez, M., Storey, B.C., \& Riley, T.R. (1998) The Chon Aike province of Patagonia and related rocks in west Antarctica: A silicic large igneous province. Journal of Volcanology and Geothermal Research 81, 113-136.

Pankhurst, R.J., Riley, T.R., Fanning, C.M., \& Kelley, S.P. (2000) Episodic silicic volcanism in Patagonia and the Antartic Peninsula: Chronology of magmatism associated with the break-up of Gondwana. Journal of Petrology 41(5), 605-625.

Panza, J.L. (1982) Descripción geológica de las Hojas 53e Gobernador Moyano y 54e Cerro Vanguardia. Servicio Geológico Nacional (inédito), 197 pp. (in Spanish). 
Panza, J.L. (1984) Descripción geológica de las Hojas 54f Bajo de la Leona y $54 \mathrm{~g}$ Bahía Laura, provincia de Santa Cruz. Servicio Geológico Nacional (inédito): 170 pp. (in Spanish).

Panza, J.L. \& Haller, M.J. (2002) El Volcanismo Jurásico. In Geología y Recursos Naturales de Santa Cruz. (M.J. Haller, ed.). Relatorio del XV Congreso Geológico Argentino 1-7, 89-101.

Panza, J.L., Márquez, M., \& Godeas, M. (1994) Hoja Geológica 4966- I y II Bahía Laura, provincia de Santa Cruz. Servicio Geológico Nacional, 83 pp. (in Spanish).

Petruk, W. \& Owens, D. (1974) Some mineralogical characteristics of the silver deposits in the Guanajuato mining district, Mexico. Economic Geology 69, 1078 1085 .

Petruk, W., Owens, D.R., Stewart. J.M., \& Murray, E.J. (1974) Observations on acanthite, aguilarite, and naumannite. Canadian Mineralogist 12, 365-369.

RAmDoHr, P. (1980) The ore minerals and their intergrowths. $2^{\text {nd }}$ Edition, Pergamon Press, Oxford, England (506-520).

Ramos, V. (1983) Evolución tectónica y metalogénesis de la Cordillera Patagónica. Congreso Nacional de Geología Económica (107-124).

Riley, T.R., Leat, P.T., Pankhurst, R.J., \& Harris, C. (2001) Origins of large volume rhyolitic volcanism in the Antarctic Peninsula and Patagonia by crustal melting. Journal of Petrology 42, 1043-1065.

Ros, C., Cevasco, C., \& Manrique, L. (2013) Actualización IIA. Estudio de Impacto Ambiental Etapa de Exploración Avanzada Proyecto Cerro Moro. Estelar Resources Limited, 318 pp. (in Spanish).

SAunders, J.A. \& BrueseKe, M. (2012) Volatility of Se and Te during subduction-related distillation and the geochemistry of epithermal ores of the Western United States. Economic Geology 107, 165-172.

Schalamuk, I.B., Zubia, M.A., Genini, A., \& Fernández, R.R. (1997) Jurassic epithermal Au-Ag deposits of Patagonia, Argentina. Ore Geology Reviews 12, 173-186.

Schalamuk, I.B., de Barrio, R.E., Zubia, M.A., Genini, A., \& Echeveste, H. (1999) Provincia auroargentífera del Deseado, Santa Cruz. In Recursos Minerales de la República Argentina (E.O. Zappettini, ed.). SEGEMAR
Instituto de Geología y Recursos Minerales, Argentina (1177-1188).

ShiKazono, N. (1978) Selenium content of acanthite and the chemical environments of Japanese vein-type deposits. Economic Geology 73, 524-533.

Sillitoe, R.H. (2009) Exploration potential of the Cerro Moro gold-silver district, Santa Cruz, Argentina. Internal report prepared for Exeter Resources Corporation, 12 pp.

Simon, G., Kesler, S.E., \& Essene, E.J. (1997) Phase relations among selenides, sulfides, tellurides, and oxides: II. Applications to selenide-bearing ore deposits. Economic Geology 92, 468-484.

Skinner, B.J. (1966) The system Cu-Ag-S. Economic Geology 61, 1-26.

Stipanicic, P. \& Bonetti, M. (1970) Posiciones estratigráficas de las principales floras jurásicas argentinas. II Floras doggerianas y málmicas. Ameghiniana 7, 101-118.

Stipanicic, P. \& Reig, A.O. (1955) Breve noticia sobre el hallazgo de anuros en el denominado "Complejo Porfírico de la Patagonia extraandina", con consideraciones acerca de la composición geológica del mismo. Revista de la Asociación Geológica Argentina 10, 215-233.

Stipanicic, P. \& Reig, A.O. (1956) El "Complejo Porfírico de la Patagonia extraandina" y su fauna de anuros. Acta Geológica Lilloana 1, 185-297.

UGARTE, F. (1966) La cuenca compuesta carbonifero-jurásica de la Patagonia Meridional. Anales de la Universidad Patagonia "San Juan Bosco" 2, 37-68.

Yamana Gold Inc. (2017) Annual information form for the fiscal year ended December 31, 2016. Yamana Gold Inc., Toronto, Ontario, Canada, 103 pp.

Yamana Gold Inc. (2018) The beginning of what's next. Yamana Gold Inc., Annual Report 2018, 180 pp.

Zappettini, E.O. (1999) Evolución geotectónica y metalogenésis de Argentina. In Recursos Minerales de la República Argentina (E.O. Zappettini, ed.). SEGEMAR Instituto de Geologia y Recursos Minerales, Argentina (51-73).

Received October 12, 2019. Revised manuscript accepted January 1, 2020. 